\title{
Câncer do Colo Uterino
}

O câncer do colo uterino é doença previsivel e pode ser prevenida tanto quanto a poliomielite entre outras tantas condições patológicas. É a neoplasia que determina o maior número de óbitos entre os cânceres ginecológicos em todo o mundo. Cerca de 500 mil novos casos são diagnosticados todo ano no mundo e cerca de 250 mil mortes ocorrerão pela doença, no mesmo espaço de tempo. (Figo, 2000).

Dados estimados do INCA projetam para o ano de 2001 cerca de 16.270 novos casos para cada grupo de 100 mil mulheres, com 3.275 mortes pela doença. No Estado do Rio de Janeiro, no mesmo ano, houve previsão de 2.130 novos casos com 420 óbitos. Este índices somente são superados pelo câncer de mama, entre as neoplasias genitais.

No Brasil, no dizer de José Focchi e Edmund Baracat (Femina 2001), falta estrutura física, é escasso o recurso humano na rede pública de saúde para controle e prevenção da neoplasia. Há poucos citopatologistas. A maioria dos laudos é emitida por citotécnicos. Há falta de padronização, seja dos laudos, seja de conduta normativa. A complementação diagnóstica com a colposcopia e biópsia é difícil na rede pública.

Deve-se, pois, louvar o recente esforço governamental do Ministério da Saúde para realização universal do exame colpocitológico para prevenção ou diagnóstico precoce da neoplasia bem como das lesões precursoras. Esperamos que estas campanhas sejam permanentes.

Há, contudo, longo caminho a ser percorrido no Brasil. Desanimar? Nunca. No dizer do poeta Virgílio, o trabalho perseverante tudo consegue "Labor omnia vincit improbus". Mas, por que a consideração? Porque os índices de aparecimento da doença estão inversamente proporcionais aos cuidados de assistência médica preventiva e ao nivel sócio-econômico e cultural de um povo.

\section{A Diretoria}

